\title{
Recovering financial sustainability of debtors: present-day legislative development trends
}

\author{
Andrey Leonidovich Belousov ${ }^{1}$ and Vandan-Ish Amarsanaa ${ }^{2}$ \\ ${ }^{1}$ Financial University under the Government of the Russian Federation (Financial University), \\ Department of Legal Regulation of Economic Operations, Moscow, Russia \\ ${ }^{2}$ University of Internal Affairs of Mongolia, Institute of Police, Department of Crime Investigation \\ Methodology, Ulaanbaatar, Mongolia
}

\begin{abstract}
The purpose of the research is to study the problems rooted in the development of relations in the sphere of bankruptcy in the Russian Federation, connected with the inefficiency of procedures aimed at financial rehabilitation of business entities, as well as to identify the main directions for further changes in the legal regulation of this area. The methodological basis was based on the application of such research methods as logical and structural analysis, systemic-functional approach, formal legalistic method. The research resulted in the disclosure of substance, features and legal regulation of such an important mechanism of market relations as a bankruptcy. As part of the research, the authors present the evaluation of law enforcement practice based on the norms of the current legislation on insolvency. A particular result of its regulatory impact is cumulatively assessed. The key problems of the law enforcement practice that has been formed within the past 20 years, as concerns the sphere of insolvency of business entities, have been formulated. The further directions of changes in legal regulation with regard to the relations in the sphere of bankruptcy in the Russian Federation have been outlined. It was concluded that, in the current situation, a change of approaches to the current bankruptcy system in favour of extending the use of rehabilitation procedures can provide significant support to businesses facing a difficult financial situation. The novelty of the research lies in a comprehensive study of the problems connected with the inefficiency of rehabilitation procedures, and in the formulation of concrete proposals for improving the legal environment in the sphere of bankruptcy.
\end{abstract}

Keywords: financial sustainability, legislation, bankruptcy

\section{Introduction}

The ongoing recession in the Russian economy, caused by objective reasons and the impact of the introduction of measures aimed at countering the pandemic, has made it necessary to revise the approaches to rehabilitation procedures in relation to debtors facing a difficult financial situation. In the conditions of objective recessionary phenomena in the Russian economic system, the search for efficient legal mechanisms for recovering debtors'

${ }^{1}$ Corresponding author: albelousov@fa.ru 
solvency, as well as securing protection of creditors' interests, remain to be the issues extremely relevant and demanded in practice.

The theoretical research of the problems connected with financial insolvency of business, carried out by the foreign scientific community, acquired momentum in the second half of the last century, when the United States proceeded to development of methods for predicting bankruptcy and recovering solvency of business entities. The initiators of the development and practical implementation of such methods were represented, as a rule, by credit institutions looking for optimal models for assessing potential debtors. Further on, the term "bankruptcy risk" became widespread in the USA, Great Britain and France. In subsequent years, quantitative methods were actively developed, both for the identification and assessment of bankruptcy risk of an enterprise and for selecting necessary rehabilitation measures to recover solvency. The most significant foreign contribution to the theoretical studies covering the said issues was made by such scholars as Altman [1], Fulmer [2], Beaver [3], Taffler [4], Klaas [5], as well as a number of other scientists.

At the same time, over the past 30 years, the Russian scientific community presented a number of significant theoretical works considering the problems of recovery of debtors' financial sustainability. The following authors can be named: Kiseleva, Gasparian, Chernysheva, Voronkova \& Androshina [6], Sheremet [7], Savitskaya [8, 9] and others.

The purpose of the research is to explore the problems underlying the development of legal relations in the sphere of bankruptcy in the Russian Federation, those connected with the inefficiency of procedures aimed at financial rehabilitation of business entities, and identification of major directions for further change in the legal regulation of this area.

\section{$2 \quad$ Methods}

The study of mechanisms for preventing bankruptcy and recovering solvency of debtors facing a difficult financial situation is based on the dialectical theory of scientific knowledge, cohesion of logical analysis and historical development, and is made with regard for the experience of the institute of bankruptcy functioning in the Russian Federation within the past 20 years [10]. In addition, the authors used the systemic approach, analysis and synthesis, induction and deduction, which in total made it possible to ensure the reliability and validity of the conclusions and proposals. A significant part of the research devoted to the institute of bankruptcy lies in the sphere of institutional economics, at the junction of economics and law.

\section{$3 \quad$ Results}

Currently, the institute of bankruptcy may be considered to be one of the most rapidly developing institutions in the legal sphere of the Russian Federation, which is accounted for by the law enforcers' demand for the mechanisms regulating this type of public relations [11]. At the same time, it should be noted that the Russian legislation regulating the relations in the sphere of bankruptcy is quite young in comparison with the foreign insolvency institutes. This is explained by the relatively short record of market relations in Russia [12]. In the conditions of a state-controlled economy, there was no objective need to carry out large-scale theoretical studies handling the problem of insolvency of business entities and to implement their results in practice [13].

It is worth noting that the Federal Law No. 127-FZ of October 26, 2002 "On Insolvency (Bankruptcy)" (hereinafter referred to as the Bankruptcy Law), which has been in effect 
since 2002, represents a third version of the basic law in the recent Russian history. Over a hundred federal laws have been adopted within more than eighteen years of its enforcement, that have introduced multiple changes and amendments to the Bankruptcy Law. Quite often, these changes were of a fundamental nature. In this regard, the present Bankruptcy Law, being much appreciable in volume and including both substantive and procedural clusters of norms, has turned into a kind of "patchwork", thus requiring complete revision. Moreover, numerous Resolutions of the Plenums of the Supreme Arbitration Court of the Russian Federation and the Supreme Court of the Russian Federation radically changed the fundamental approaches to regulating bankruptcy, through their practice in a number of cases, and continue to change them; in fact, the courts appear to replace the legislative power [14].

At the same time, the provisions underlying the Bankruptcy Law, aimed both at preventing bankruptcy and recovering debtor's solvency, proved not to be working in practice.

Addressing the statistical data for the last six years, one can see that rehabilitation procedures (external management and financial recovery) are more or less efficient in a minor percentage of cases; moreover, this indicator tends to go down. For instance, if one analysis the data provided by the Unified Federal Register of Bankruptcy Information (hereinafter - UFRBI), one may see a decrease in the scope of rehabilitation procedures, both in quantitative terms and as a percentage of court judgements on declaring a debtor bankrupt (Fig. 1) [15].

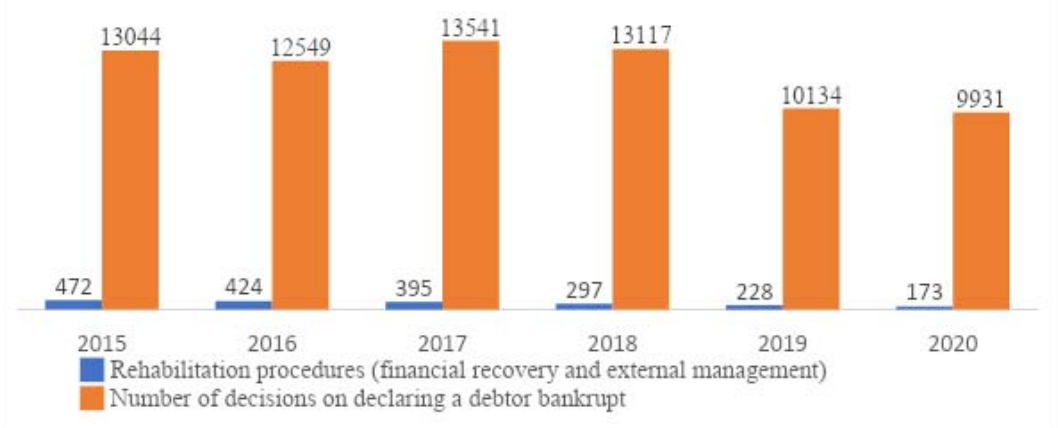

Fig. 1. Applied rehabilitation procedures in the total mass of bankruptcy cases.

In this regard, the purpose of the study was to develop specific proposals for amending the current legislation governing the bankruptcy procedure. These proposals are based on the analysis of the law enforcement practice in bankruptcy cases over the past 20 years, as well as the foreign experience of the practical application of the models for debtors' solvency recovery, along with the study of the national solutions for the implementation of financial recovery tools in the legal sphere, with regard for the specifics of business and external environment conditions in the Russian Federation.

It can be noted, as a conclusion, that the change in approaches to bankruptcy procedures, with an emphasis on broader use of rehabilitation procedures that allow a debtor to stay afloat, is a correct and absolutely logical step towards the further formation of a modern legal framework regulating the relations in the sphere of insolvency. The changes 
in the legal environment in the given area will make it possible to predict a reduced level of non-payments in the economy in the future and to ensure full-value protection of the interests of both creditors and debtors. This issue acquires particular significance in the conditions of the recessionary phenomena taking place in the Russian economic system against the backdrop of restrictions and prohibitions caused by the need to confront the pandemic.

\section{Discussion}

In view of the above, the legislator's attention in developing proposals for reforming the regulatory framework in this sphere should be aimed at changing the approaches to the practiced rehabilitation procedures [16]. Turning to the accumulated experience of applying the bankruptcy rules, one can see that it is the financial recovery and external management, in the first place, that demonstrate inadequacy as working instruments within the framework of the insolvency legislation. Therefore, the said procedures should be abolished in the form as they are practiced today [17]. The ensuing question is: what is the alternative and what practices should replace them.

When rejecting financial rehabilitation and external management in favour of a different procedure for recovering debtor's solvency, it is necessary to build the legal framework in a way permitting the increasing number of insolvent entities to eventually acquire financial sustainability and stay afloat. In the conditions of the general crisis in the economy, this will secure job conservation and due maintenance of the taxable base without its reduction [18]. It seems justified to use the gained five-year experience of individuals' bankruptcy in this case. This institute has been implemented in practice since October 1, 2015 and, with some reservations, has garnered quite a successful functional experience. The rehabilitation procedures normally used relative to individuals as insolvency handling instruments should be applied in respect of legal entities, being properly selected and adapted. In a number of cases, when developing and substantiating transparent criteria, it is feasible to make these procedures mandatory for business entities. By analogy with the norms developed for individuals' bankruptcy procedures, it is possible to introduce mandatory instalments for a period of up to three years for the redemption of accrued debt obligations. This will make it possible to withdraw from the vicious practice, that has formed today, when bankruptcy commissioners are in fact engaged in liquidation of debtors instead of attempting to restore the debtor's solvency.

Another key task aimed at preserving the existing business of a debtor without causing significant damage to the creditors' interests is the development of tools for pre-trial settlement of disputes in the legal sphere. Such mechanisms make it possible to smooth out the growing financial problems in due time and to prevent a drop of the debtor's financial sustainability to critical levels. The international practice has accumulated significant experience of applying such pre-trial dispute resolution instruments. For instance, the practice of foreign companies includes a number of mechanisms for arranging out-of-court workouts with creditors, "prepackaged bankruptcy" and prepackaged sale of troubled business, deals involving merger and acquisition of distressed companies. Some examples of the use of such mechanisms already exist in the domestic practice; however, at present their enforcement is limited due to the fact that they have not been properly enshrined in the Russian legislation.

Another important longstanding problem in regulating the bankruptcy process in the Russian Federation is a major difficulty in identifying the debtor's ultimate beneficiaries. The presence of the so-called "corporate veil" in the Russian legal environment 
significantly complicates the identification of ultimate beneficiaries in the event of debtor's insolvency. At the same time, the doctrine of "piercing the corporate veil" has been practiced in the Russian Federation in a number of court judgements since 2012. In general, the concept of "piercing the corporate veil" in the Anglo-Saxon legal system or "peeping behind the corporate veil" (Durchgriff hinter den gesellschaftsrechtlichen Schleier) in the European legal framework means that liability for breach of obligations by a company, under certain conditions, is imposed on the entities who fully control it - if the company in fact represents their "vehicle", a formal cover for their unfair activities.

\section{Conclusion}

Thus, the sustainable development of business today remains one of the key issues both in the present-day Russian economic science and in the activities of legislative and executive authorities at all levels. At the same time, of particular importance in the conditions of the recession of the Russian economy is the creation of the institutional environment preventing the bankruptcy of economic entities and providing opportunities for recovering solvency of businesses that have already faced a difficult financial situation.

The article was prepared based on the results of research funded through budget resources under a state assignment of the Financial University under the Government of the Russian Federation.

\section{References}

1. E.I. Altman, Journal of Credit Risk, 14(4) (2018). Accessed on: June 30, 2021. [Online]. Available: http: https://ssrn.com/abstract=3299519

2. G.A. Fulmer, Journal of Commercial Bank Lending 25-37 (1984)

3. W.H. Beaver, S. Cascino, M. Correia, M. McNichols, Management Science, 65(8), 3559-3584 (2019)

4. R.J. Taffler, The assessment of financial viability and the measurement of company performance (City University Business School, 1981)

5. T.A. Klaas, Models of forecasting of financial instability and bankruptcy of the company, in K. Orzechowska (ed.), The Third International Conference on Economic Sciences. Proceedings of the Conference, 116-123 (2014)

6. I.A. Kiseleva, M.S. Gasparian, E.N. Chernysheva, T.N. Voronkova, I.S. Androshina, International Journal of Recent Technology and Engineering, 8(2), 6304-6310 (2019)

7. A.D. Sheremet, Audit, 5, 6-9 (2017)

8. G.V. Savitskaya, Digest Finance, 23(3), 274-288 (2018). https://doi.org/10.24891/df.23.3.274

9. G.V. Savitskaya, Chief Financial Officer, 3, 40 (2016)

10. A.L. Belousov, Actual Problems of Economics and Law, 14(1), 5-21 (2020)

11. Z. Affes, R. Hentati-Kaffel, Annals of Operations Research (2018). https://doi.org/10.1007/s10479-018-2845-8

12. V. Garca, A.I. Marques, J. Salvador Sanchez, Information Fusion, 47, 88-101 (2019)

13. L.N. Pavlova, Bulletin of Plekhanov Russian University of Economics, 1(109), 5-15 2020.

14. I.V. Frolov, Entrepreneurial Law, 1, 30-38. 2020 
15. Unified Federal Register of Bankruptcy Information (UFRBI). Accessed on: February 16, 2021. [Online]. Available:

http://download.fedresurs.ru/news/\%D0\%91\%D0\%B0\%D0\%BD\%D0\%BA $\% \mathrm{D} 1 \% 80$ $\% \mathrm{D} 0 \% \mathrm{BE} \% \mathrm{D} 1 \% 82 \% \mathrm{D} 1 \% 81 \% \mathrm{D} 1 \% 82 \% \mathrm{D} 0 \%$ B2\% D0\% B0\% 20\% D1\% 81\% D1\% $82 \%$ D0\% B0\% D1\% 82\% D1\% 80\% D0\% B5\% D0\% BB\% D0\% B8\% D0\% B7\% $20 \%$ D0\% A4 \% D0\% B5\% D0\% B4\% D1\% 80\% D0\% B5\% D1\% 81\% D1\% 83\% D1\% 80\% D1\% 81\% 202020.pdf

16. I.S. Zubarev, Moscow Journal, 3, 48 (2020)

17. P.A. Menshikova, Arbitration and Civil Procedure, 4, 52-55 (2020)

18. A.L. Belousov, Search for mechanisms of economic growth through changing the approaches to insolvency procedures for small and medium-size businesses, in the collection: Modernisation of Russian society and education: new economic guidelines, management strategies, issues of law enforcement and staff training. Materials of $21^{\text {st }}$ National Scientific Conference with international participation, 72-74 (2020) 